\title{
SCANNING ELECTRON MICROSCOPY AND ELECTRON MICROPROBE ANALYSIS OF SILICIFICATION PATTERNS IN INFLORES- CENCE BRACTS OF AVENA SATIVA ${ }^{1}$
}

\author{
Peter B. Kaufman, J. Donald LaCroix, ${ }^{2}$ Jonathan J. Rosen, \\ LaWrence F. Allard, and Wilbur C. Bigelow \\ Department of Botany and Department of Materials and Metallurgical Engineering, \\ University of Michigan, Ann Arbor 48104
}

A B S T R A C T

Using scanning electron microscopy, we determined the kinds and distribution of epidermal cell types in Avena inflorescence bracts (glume, lemma, and palea). Electron microprobe analysis of silica deposition in these epidermal cells showed that silica cells constitute one of the important deposition sites. Probe ratio data indicate that the silica deposited is $74 \%$ pure. Significant amounts of silica also become deposited in the trichomes and lesser amounts in the walls of long epidermal cells. None could be detected in the stomata. The possible functional significance of silica deposition in epidermal cells of these bracts is discussed.

IN PREVIOUS STUDIES involving electron probe analysis, we examined silicification patterns in the epidermal system of the internode and leaf of the oat plant (Kaufman et al., 1969; Soni, Kaufman, and Bigelow, 1970). The silica is localized in the walls of long epidermal cells, in silica cells of cork-silica pairs, in trichomes, and in guard and subsidiary cells of the internode. Cork cells have no detectable silica.

There is a paucity of information on both the morphology (Frohnmeyer, 1914) and silicification patterns of inflorescence bracts of grasses. The epidermis of Avena inflorescence bracts (glume, lemma, and palea) basically consists of long epidermal cells, silica cells, trichomes, and stomata (Hector, 1936). By means of scanning electron microscopy Baum (1971) described and illustrated the sculpture of the surfaces of caryopses, glumes, lemmas, awn columns, and awn subules in several species of Avena. However, this study was taxonomic, with no information on silicification patterns. Bonnett (1961) studied inflorescence bracts in Avena and presented data on the early stages of development of glume, lemma, and palea primordia. Prat (1932) examined inflorescence bracts of many genera and described and illustrated some of the cell types of the epidermal system.

The primary objectives of the present study were: (1) to determine which cells of the outer epidermal system become silicified, (2) to assess the relative amounts of silica $\left(\mathrm{SiO}_{2}\right)$ in those epidermal cells which accumulate it compared with pure silicon $(\mathrm{Si})$, and (3) to analyze variations in silicification patterns among the three

\footnotetext{
1 Received for publication 15 March 1972.

2 Present address: Department of Biology, University of Detroit, Detroit 48221.

The authors wish to thank Mr. Louis Martonyi for his help with the photographic work.
}

types of bracts as well as from top to base of each bract.

Materials AND METhods-Plants of Avena sativa L. cv. 'Victory' were grown in the greenhouse under a photoperiod regime of $18 \mathrm{hr}$ light and $6 \mathrm{hr}$ dark. The average day temperature was $26 \mathrm{C}$ and the night temperature $22 \mathrm{C}$. At 55-60 days after planting the panicles had emerged and formed well-differentiated florets. Mature glumes, lemmas, and paleas were excised and pieces of outer epidermal tissue, ca. $2 \mathrm{~mm}$ square, were removed from the top, middle, and base of each type of bract. The pieces of tissue were placed in $2-\mathrm{cm}$ square aluminum foil envelopes, immediately frozen in liquid nitrogen, and then freezedried in a vacuum desiccator for $48 \mathrm{hr}$.

For scanning electron microscopy, the dried pieces of tissue were mounted with collodion on 200-mesh copper electron microscope specimen grids, dried, mounted on aluminum stubs, and coated with a fine layer of gold. These preparations were stored over $\mathrm{CaCl}_{2}$ in an airtight box until ready for observation. The scanning electron microscope, hereafter referred to as the SEM (JEOL model JSM-U3), was normally operated at $25 \mathrm{kev}$ accelerating potential, but in several instances lower voltages were used to minimize charging artifacts in the images. SEM secondary electron images were recorded on Polaroid Type $55 \mathrm{P} / \mathrm{N} 4 \times 5$ film.

For electron probe analysis, the dried pieces were mounted on polished copper squares with electrically conductive silver paint. The tissue was then coated with a thin layer of carbon and stored in a desiccator until examination. The electron microprobe, hereafter referred to as the EMP (Applied Research Laboratories, model EMXSM), was operated at $20 \mathrm{kev}$, providing an electron-beam penetration of about $15 \mu \mathrm{m}$, which 

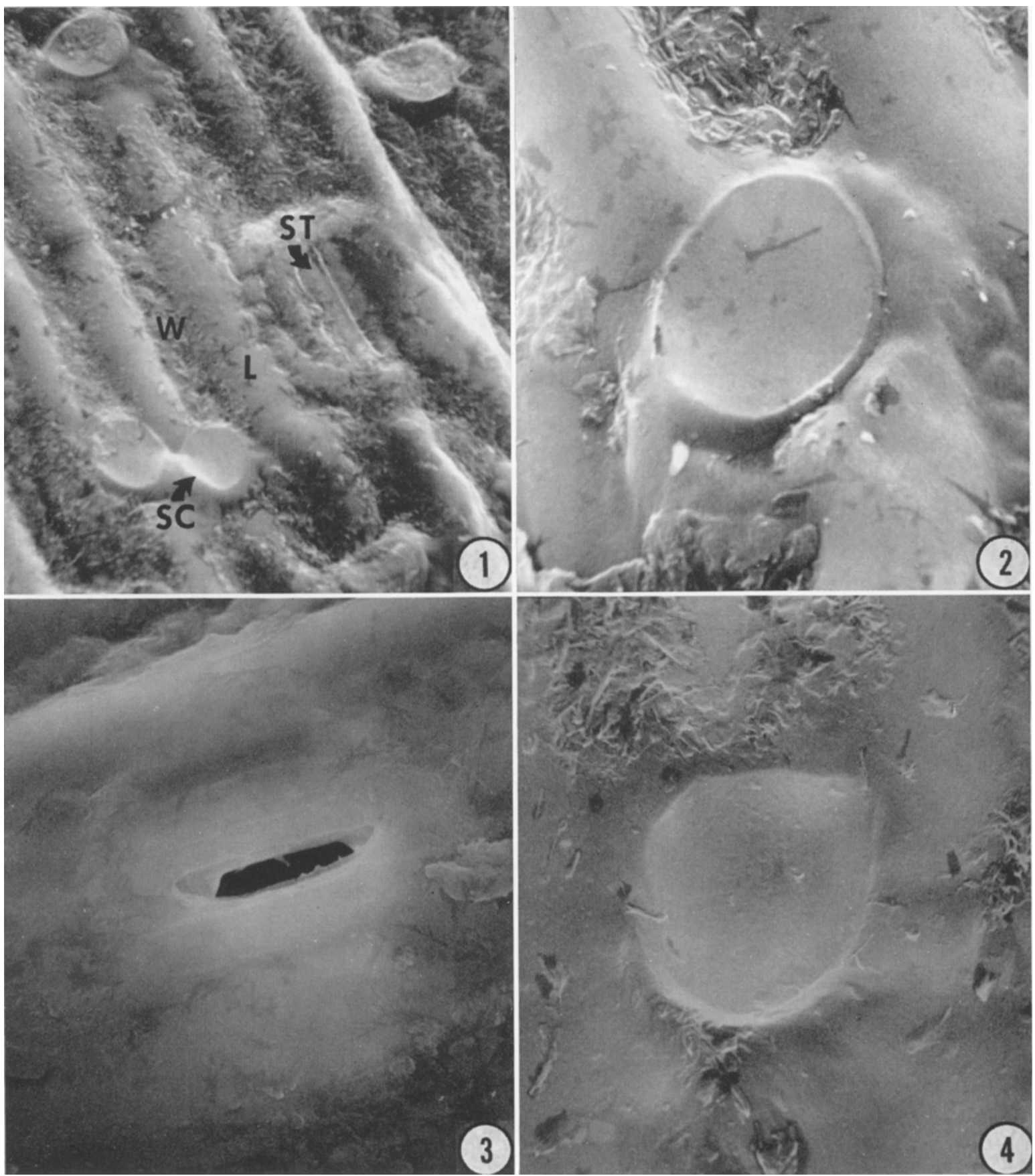

Fig. 1-4.-Fig. 1. SEM view of the outer surface of an Avena glume, illustrating silica cells (SC), a stomatal apparatus with aperture closed $(S T)$, and long epidermal cells. Light ridges $=$ lumina of long cells $(L)$ and corrugated structures on either side of each ridge = long cell walls $(W) . \times 1000$.-Fig. 2 . Enlarged SEM illustration of a raised circular "platform," which is a silica cell, and associated long epidermal cells in the glume. $\times 3000 .-$ Fig. 3. Illustration of stomatal apparatus (aperture open) on glume outer epidermis. $\times 2000$. Fig. 4. Silica cell appearing as a circular raised "platform" on outer surface of the lemma. $\times 3000$.

is the average thickness of the epidermal layer. The beam current was $0.20 \mu$ amps, giving a sample current of $0.021 \mu \mathrm{amps}$. The X-ray spectrometer was peaked for the first-order silicon
$\mathrm{K}$ alpha line, using an ammonium dihydrogen phosphate (ADP) crystal. Secondary electron images were employed to examine the tissue and to select cells for analysis. EMP secondary elec- 
TABLE 1. Electron microprobe analysis giving probe ratios ${ }^{\mathrm{a}}$ of $\mathrm{SiO}_{2}$ containing structures in outer epidermis of Avena sativa inflorescence bracts

\begin{tabular}{|c|c|c|c|c|c|c|c|c|c|c|}
\hline \multirow[b]{3}{*}{ Cell Type } & & \multicolumn{9}{|c|}{ Inflorescence Bract } \\
\hline & & \multicolumn{3}{|c|}{ Glume } & \multicolumn{3}{|c|}{ Lemma } & \multicolumn{3}{|c|}{ Palea } \\
\hline & & Top & Middle & Base & Top & Middle & Base & Top & Middle & Base \\
\hline Long Cell Wall & $\begin{array}{r}\mathrm{Si}^{\mathrm{b}} \\
\mathrm{SiO}_{2}{ }^{\mathrm{c}}\end{array}$ & $\begin{array}{l}0.030 \\
0.064\end{array}$ & $\begin{array}{l}0.024 \\
0.051\end{array}$ & $\begin{array}{l}0.119 \\
0.255\end{array}$ & $\begin{array}{l}0.014 \\
0.029\end{array}$ & $\begin{array}{l}0.067 \\
0.143\end{array}$ & $\square^{\mathrm{d}}$ & $\begin{array}{l}0.280 \\
0.599\end{array}$ & $\begin{array}{l}0.227 \\
0.486\end{array}$ & $\square^{\mathrm{d}}$ \\
\hline Silica Cell & $\begin{array}{r}\mathrm{Si} \\
\mathrm{SiO}_{2}\end{array}$ & $\begin{array}{l}0.151 \\
0.323\end{array}$ & $\begin{array}{l}0.347 \\
0.742\end{array}$ & $\begin{array}{l}0.274 \\
0.586\end{array}$ & $\begin{array}{l}0.292 \\
0.624\end{array}$ & $\begin{array}{l}0.311 \\
0.665\end{array}$ & $\begin{array}{l}0.347 \\
0.742\end{array}$ & $\begin{array}{l}0.283 \\
0.605\end{array}$ & $\begin{array}{l}0.347 \\
0.742\end{array}$ & $\begin{array}{l}0.332 \\
0.710\end{array}$ \\
\hline Trichome & $\begin{array}{r}\mathrm{Si} \\
\mathrm{SiO}_{2}\end{array}$ & $\begin{array}{l}0.196 \\
0.419\end{array}$ & $\begin{array}{l}0.224 \\
0.479\end{array}$ & $\overline{-}^{\circ}$ & $\begin{array}{l}0.271 \\
0.580\end{array}$ & $\begin{array}{l}0.333 \\
0.712\end{array}$ & $\bar{\square}^{\circ}$ & $\begin{array}{l}0.339 \\
0.725\end{array}$ & $\begin{array}{l}0.174^{\mathrm{f}} \\
0.372^{\mathrm{f}}\end{array}$ & $\bar{\square}^{\mathrm{c}}$ \\
\hline Background ${ }^{\mathrm{z}}$ & $\begin{array}{r}\mathrm{Si} \\
\mathrm{SiO}_{2}\end{array}$ & $\begin{array}{l}0.011 \\
0.024\end{array}$ & $\begin{array}{l}0.009 \\
0.019\end{array}$ & $\begin{array}{l}0.010 \\
0.021\end{array}$ & $\begin{array}{l}0.009 \\
0.019\end{array}$ & $\begin{array}{l}0.025 \\
0.053\end{array}$ & $\begin{array}{l}0.002 \\
0.004\end{array}$ & $\begin{array}{l}0.006 \\
0.013\end{array}$ & $\begin{array}{l}0.047 \\
0.101\end{array}$ & $\begin{array}{l}0.036 \\
0.077\end{array}$ \\
\hline
\end{tabular}

${ }^{a}$ Probe ratio is the peak minus background of sample/peak minus background of standard.

${ }^{b}$ Data based on direct measurements of silicon ( $\mathrm{Si}$ ).

c Data based on silica $\left(\mathrm{SiO}_{2}\right)$ standard (see methods).

${ }^{d} \mathrm{SiO}_{2}$ not observed in cells at this level of bract.

- Trichomes not observed at this level of bract.

${ }^{\mathrm{P}}$ Data obtained from lateral rather than surface trichomes.

${ }^{g}$ Lowest peak counts found on sample.

tron and X-ray images were recorded on Type 42 Polaroid Polapan Land Roll $3^{1 / 4} \times 4^{1 / 4}$ film.

A semiquantitative comparison of differing $\mathrm{Si}$ levels was made for each tissue section in conjunction with the Si X-ray distribution maps. This digital information has been reported (Table 1) as the ratio of counts taken on the sample (peak minus background) to the counts taken on a pure Si standard (peak minus background) under constant and identical instrument conditions. This probe ratio does not represent an exact weight percentage for the amount of $\mathrm{Si}$ present because no correction has been made for fluorescence, absorption, or atomic number effects (Beaman and Isasi, 1971). Electron drift effects have been automatically corrected by using current-controlled counting times. Although the probe ratio does not represent an exact weight percent, it does afford a more precise measure of relative values and a semiquantitative comparison with respect to pure $\mathrm{Si}$ than reporting the raw data as counts per second. To approximate the weight percent of $\mathrm{SiO}_{2}$ present in the samples, a standard probe ratio of counts on an $\mathrm{SiO}_{2}$ standard versus counts on an Si standard was obtained. This value was used to modify the Si-based probe ratios.

Since there is clear evidence that $\mathrm{Si}$ is associated with oxygen as $\mathrm{SiO}_{2}$ in biological material (Lewin and Reimann, 1969), and especially as noncrystalline isotropic silica gel $\left(\mathrm{SiO}_{2} \cdot \mathrm{nH}_{2} \mathrm{O}\right)$ in grasses such as Avena (Jones and Milne, 1963; Lewin and Reimann, 1969), we assume this to be the case with Avena inflorescence bracts. Because of the difficulty of measuring oxygen directly with the EMP, especially in biological material, we measured only Si. Therefore, in this paper, we refer to $\mathrm{Si}$ with reference to our direct measure- ments with the EMP (Table 1) and $\mathrm{SiO}_{2}$ as the probable form in which $\mathrm{Si}$ occurs in Avena inflorescence bracts.

Results-Analysis of the outer surfaces of glume, lemma, and palea with SEM.-The surfaces of the glume, lemma, and palea in Avena are highly corrugated on their outer surfaces (Fig. $1,12,20)$. The primary elements of the epidermal system on these surfaces include a basic matrix of long epidermal cells with undulating walls. Intercalated among these cells are three kinds of idioblasts: silica cells, trichomes, and stomata (Fig. 1, 6, 7, 14).

The silica cells vary markedly in structure on the three different inflorescence bracts. Typically, they are most numerous towards the bases of the glume and lemma and appear as rounded, raised "platforms" with more or less shallow, concave surfaces (Fig. 1, 2, 4). On the palea, usually near the base, the silica cells vary from almost indistinguishable short cells in the plane of the long epidermal cells between the trichomes (Fig. 7) to raised "platforms," connected accentrically to the long cell lying immediately below (Fig. 5, 6). These latter raised "platforms" appear to reside in conspicuous depressions below the overlapping "flaps" of the silica cells (Fig. 6). It is thus seen that silica cells of the outer epidermis attain their most bizarre and differentiated state in the basal portions of the paleas, the innermost of the inflorescence bracts.

The trichomes are most numerous towards the tips of the bracts (Fig. 7, 16). They are extremely sharp pointed, and the basal portions are covered with masses of heterogenously dispersed cuticle (Fig. 9). Most of these trichomes are borne on 


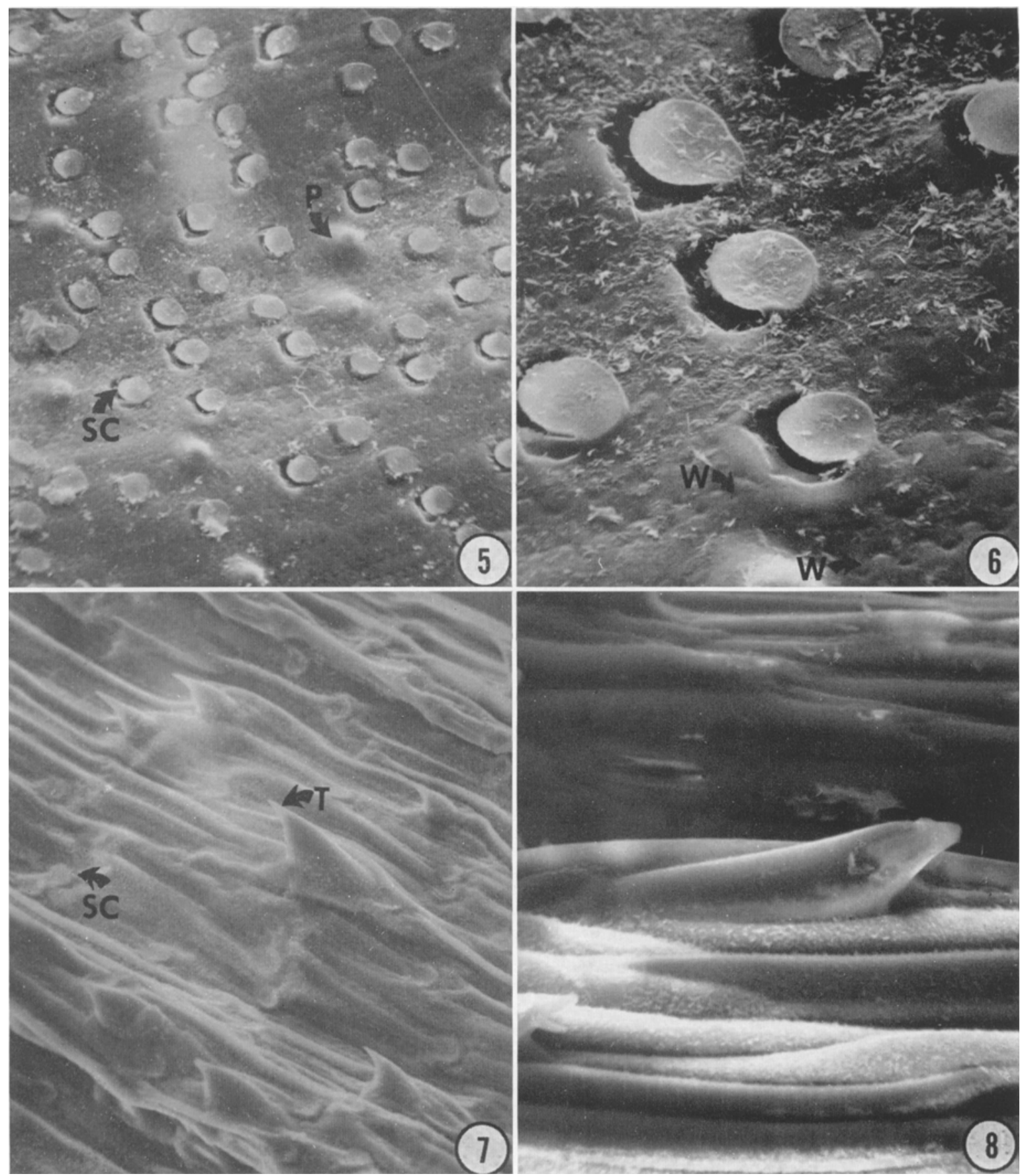

Fig. 5-8.-Fig. 5. SEM view of the outer surface of an Avena palea, illustrating prickles (P) and highly differentiated circular, raised "platforms" which are the silica cells $(\mathrm{SC}) . \times 300 .-$ Fig. 6 . Enlarged view of silica cells on palea. They are attached accentrically with the overhanging "lips" lying above distinct depressions in the epidermis. Undulate walls of long epidermal cells $(W)$ are also apparent. $\times 1000 .-$ Fig. 7 . SEM view of palea outer surface near tip, illustrating numerous trichomes $(\mathrm{T})$ and silica cells $(\mathrm{SC}) . \times 300 .-$ Fig. 8 . Close-up view of a palea trichome intercalated between the numerous ridge-like, long epidermal cells (LC). $\times 750$.

the ridges of the bract surface. Near the bract tips, as in the palea, they are the dominant feature in most of the rows of epidermal cells (Fig. 7, 16).

The stomata occur in rows on the flanks of the ridges on the bract surfaces. The SEM views in our preparations indicate very deep fissures, representing the apertures of the stomata (Fig. 3, $10)$. 


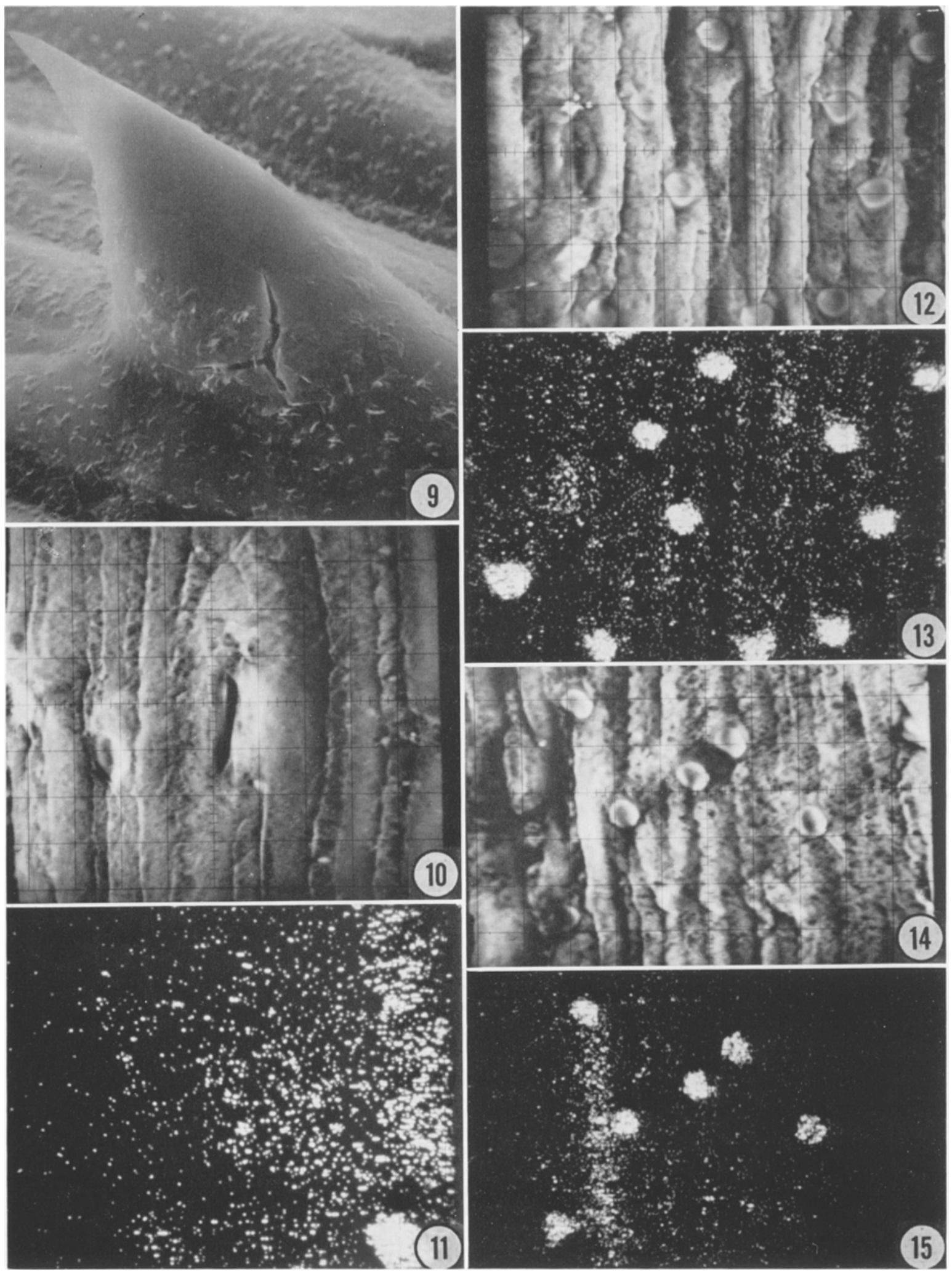

Fig. 9-15.-Fig. 9. SEM illustration of a trichome from upper part of a palea, showing relatively smooth upper surface and abundance of cuticle on basal portion. $\times 2000$.-Fig. 10-15. EMP secondary electron (Fig. 10, 12, 
Analysis of $\mathrm{SiO}_{2}$ deposition in the outer epidermal cells of glume, lemma, and palea with $E M P$. - In the glume, we find that $\mathrm{SiO}_{2}$ is primarily deposited in the walls of the long epidermal cells, in silica cells, and in trichomes. The semiquantitative analysis, using probe ratios, indicates that the silica cells and trichomes clearly contain considerably more $\mathrm{SiO}_{2}$ than the walls of the long epidermal cells (Table 1). In the silica cells we obtain probe ratios, based on $\mathrm{SiO}_{2}$, of 0.323 (top) to 0.742 (middle); in the trichomes 0.419 (top) to 0.479 (middle); and in the walls of the long epidermal cells 0.051 (middle) to 0.255 (base).

In the lemma $\mathrm{SiO}_{2}$ (Fig. 15) occurs primarily in silica cells (Fig. 14) and trichomes, with much less in the walls of long epidermal cells (Table 1). Occasionally, the outer tangential walls of the long epidermal cells (Fig. 14) contain substantial amounts of $\mathrm{SiO}_{2}$ (Fig. 15). In the upper part of the lemma there are fewer silica cells.

The palea tip is covered with trichomes (Fig. 16). These are the primary deposition sites for $\mathrm{SiO}_{2}$ at this level of the bract (Fig. 17). Few silica cells occur at this level. The probe ratio data (Table 1) indicate slightly higher amounts of silica in the trichomes than in the silica cells. Just below the tip of the palea, we encounter numerous silica cells and fewer trichomes. At this level both these types of cells are the primary centers for $\mathrm{SiO}_{2}$ accumulation (Fig. 18, 19). The middle and basal portions of the palea contain an enormous number of raised, discoid silica cells (Fig. 5, 20). They are clearly "selected" sites for $\mathrm{SiO}_{2}$ deposition at these levels (Fig. 21). The probe ratio values for $\mathrm{SiO}_{2}$ in these cells (Table 1) varied between 0.710 and 0.742 . Significant but lesser amounts of $\mathrm{SiO}_{2}$ also occur in walls of long epidermal cells at the middle of the palea (Fig. 20, 21), being about $60 \%$ of that measured in the silica cells at this level.

No significant increase in amount of $\mathrm{SiO}_{2}$ over that in surrounding epidermal cells could be detected in stomata on the lemma (Fig. 12, 13) or on either the glume or palea.

From the above data, we conclude: (1) that silica cells and trichomes constitute the primary accumulation sites for $\mathrm{SiO}_{2}$ on the top, middle, and basal portions of each inflorescence bract; (2) that lower but significant amounts of $\mathrm{SiO}_{2}$ become deposited in walls of long epidermal cells of each bract; and (3) that the stomata are not significant sites for the accumulation of $\mathrm{SiO}_{2}$ in the inflorescence bracts.
Discussion-The deposition sites for $\mathrm{SiO}_{2}$ in Avena inflorescence bracts are the silica cells over most of the bract surface, the numerous trichomes near the tip of each bract, and walls of long epidermal cells. It appears from this study that $\mathrm{SiO}_{2}$ is selectively deposited in these structures and not in the stomata nor in the lumina of long epidermal cells. The pattern is essentially the same in each of the bracts except for the fact that silica cells (raised "platforms") occur with much higher frequency on the outer surface of the palea than on the other bracts. Such a pattern is similar to that of the Avena leaf (Soni et al., 1970) but different from Avena internode, where $\mathrm{SiO}_{2}$ is also found in guard and subsidiary cells of the stomatal apparatuses (Kaufman et al., 1969). Because the long cells are so much shorter in inflorescence bracts than in leaf and internode, there are far more silica cells per unit area in the bracts, and hence, there is a much more striking pattern of deposition sites for $\mathrm{SiO}_{2}$ in these structures (Fig. 10, 11, 20, 21).

What is the adaptive significance for such patterns of $\mathrm{SiO}_{2}$ deposition in the inflorescence bracts? Clearly, the inclusion of $\mathrm{SiO}_{2}$ in the walls of long epidermal cells, presumably intercalated among the cellulose microfibrils (Siegel, 1968), would provide support in addition to that of the cellulosic polysaccharides, as we have indicated for walls of long epidermal cells in the internode (Kaufman et al., 1969). The $\mathrm{SiO}_{2}$ in these cell walls could also restrict transpirational water loss by hydration of the silica gel. The $\mathrm{SiO}_{2}$ in the hairs could provide both mechanical support and protection against attack by insects and other predators. The silica cells, where $\mathrm{SiO}_{2}$ is irreversibly accumulated, must apparently constitute deposition sites for excess silicic acid in the transport system. These cells are probably sites where water is conserved in the bract through hydration of the silica gel deposited there.

The silicification process in these bracts, as indicated by the deposition patterns, must be highly selective. The "preferred" sites are the walls of trichomes and long epidermal cells and the lumina of the silica cells, as inferred from our previous studies with electron microscopy (Kaufman, Petering, and Smith, 1970) and electron probe analysis (Kaufman et al., 1969; Soni et al., 1970) on similar cells in the internode and leaf of Avena. Our hypothesis is that in living cells such as trichomes and long epidermal cells, the $\mathrm{SiO}_{2}$ is somehow excluded by the plasmalemma so that silica gel polymerizes from silicic acid on cellulose microfibrils of the cell wall. By con-

14) and X-ray images (Fig. 11, 13, 15) of same areas.-Fig. 10, 11. Base of glume. $\times$ 500.-Fig. 12, 13. Top of lemma. $\times 1000 .-$ Fig. 14,15 . Middle of lemma. $\times 500$. Circular areas on secondary electron images are silica cells, also seen as discrete more or less circular white areas on the $X$-ray images. 

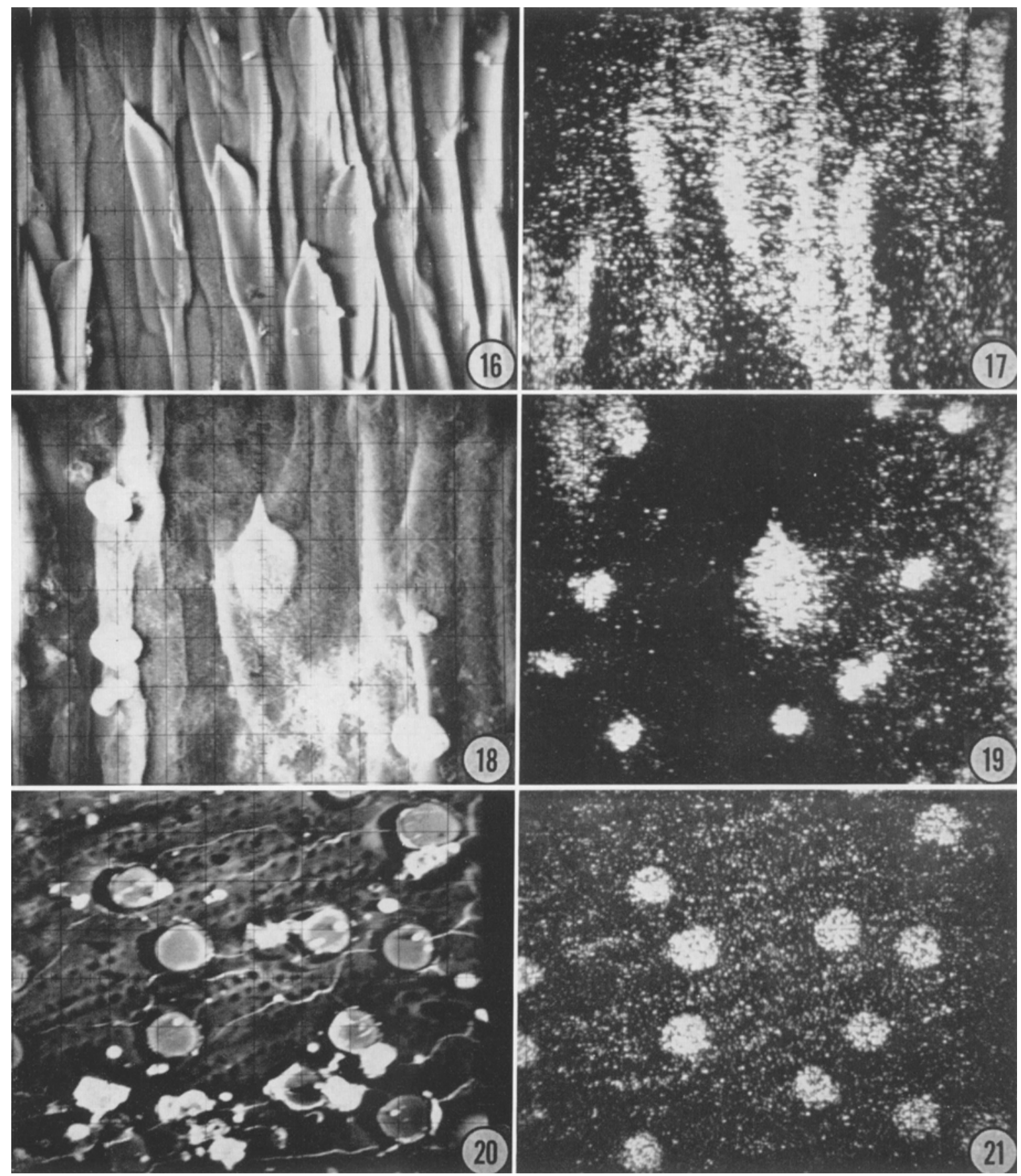

Fig. 16-21. EMP secondary electron (Fig. 16, 18, 20) and X-ray images (Fig. 17, 19, 21) of same areas.-Fig. 16, 17. Extreme apical part of palea. $\times 400 .-$ Fig. 18,19 . Apical part just below tip of palea. $\times 500 .-$ Fig. 20 , 21. Middle part of palea. $\times 500$.

trast, in silica cells, where all the membranes and organelles break down by some unknown lytic process during their development (Kaufman et al., 1970), the silicic acid would polymerize preferentially on breakdown products of membranes and organelles in the cell lumen, thus forming the long bead-like chains of silica bodies seen in these cells. Why the $\mathrm{SiO}_{2}$ is excluded from stomatal walls in these bracts as well as the leaves, but not in the internode, is unknown and needs to be studied further.

The silica cells in Avena inflorescence bracts 
are not associated with cork cells as in the internode and are clearly much more highly differentiated in the bracts. Their development into raised "platforms" needs to be studied in detail and coupled with analysis of the silicification process as they differentiate.

\section{LITERATURE CITED}

BaUm, B. R. 1971. Additional taxonomic studies on Avena fatuoids: some morphological attributes seen using the scanning electron microscope. Can. J. Bot. 49: 647-649.

Beaman, D. R., and J. A. Isasi. 1971. Electron beam microanalysis. Mater. Res. Standards 11: 12-56.

BonNETT, O. T. 1961. The oat plant: its histology and development. Bull. 672. Univ. Ill. Agr. Exp. Sta., Urbana.

Frohnmeyer, Max. 1914. Die Entstehung und Ausbildung der Kieselzellen bei den Gramineen. Bibl. Bot. 86: 1-41.

Hector, J. M. 1936. Oat species (Avena), p. 21-91. In, Introduction to the botany of field crops. Vol. I. Cereals. Central News Agency Ltd., Johannesburg, South Africa.
Jones, L. P. H., AND A. A. Milne. 1963. Studies of silica in the oat plant. I. Chemical and physical properties of the silica. Plant Soil 18: 207-220.

Kaufman, P. B., W. C. Bigelow, L. B. Petering, and L. B. Drogosz. 1969. Silica in developing epidermal cells of Avena internodes: Electron microprobe analysis. Science 166: 1015-1017.

$\longrightarrow$, L. B. Petering, AND J. G. SMith. 1970. Ultrastructural development of cork-silica cell pairs in Avena internodal epidermis. Bot. Gaz. 131: 173185.

Lewin, J. C., and B. E. F. Remmann. 1969. Silicon and plant growth. Annu. Rev. Plant Physiol. 20: 289-304.

Prat, H. 1932. L'épiderme des Graminées. Étude anatomique et systématique. Ann. Sci. Natur. Bot. 14: $117-324$.

SiegEL, S. M. 1968. Biochemistry of the plant cell wall, p. 1-51. In M. Florkin and E. H. Stotz [ed.], Comprehensive biochemistry. Elsevier, Amsterdam.

Soni, S. L., P. B. Kaufman, and W. C. Bigelow. 1970. Electron microprobe analysis of the distribution of silicon in leaf epidermal cells of the oat plant (Avena sativa L.). Phytomorphology 20: 350-363. 